\title{
Article
}

\section{One of 2G Bioethanol Queries: Straw Volume}

\author{
Yangsheng $\mathrm{Lu}^{1 *}$, Robert S.P. Liu ${ }^{2}$ and Jens Kirk Thomsen ${ }^{1,}$ \\ 1 International Starch Institute, 8200 Aarhus, Denmark; info@starch.dk \\ 2 RSL \& Associates, Laguna Hills, CA 92653-6102, USA; robert.liu@sbcglobal.net \\ * Correspondence: starchtech@hotmail.com ; Tel.: +45- 88438800
}

\begin{abstract}
There are some controversies about 2G bioethanol and it is in need of a reliable test data in order to make a further analysis and proof. In collecting basic data from three classes of typical raw materials, such as wheat, maize stalk juice, and straw, it was found that 4.32 tons straw or 3.358 tons wheat is needed to produce 1 ton bioethanol. Using the coefficient of variation calculation and analysis method, it is able to obtain the C.V. value of straw fermentation efficiency $0.08932<0.15$, indicating the fermentation technology and process of $2 \mathrm{G}$ bioethanol is already quite mature and reliable, without risk, and also with a raw material cost advantage. There is a problem in that the C.V. value of straw volume is $1.2648>0.95$, indicating $2 \mathrm{G}$ bioethanol is in an extremely high-risk area. Using the straw volume calculation method, building and its costs - capital expenditure of $2 \mathrm{G}$ bioethanol plant is approximately seven times that of a wheat ethanol plant. This should be some of the important reasons why it is noncompetitive, extremely high price, and requiring government subsidies. Straw volume data study has caused the $2 \mathrm{G}$ bioethanol plant to require more cement, steel, equipment, and other materials. Thus, there are ample reasons to question the $\mathrm{CO} 2$ emissions and its carbon footprint of $2 \mathrm{G}$ bioethanol plant. Actually, the volume is not the only existing problem, it is necessary to re-evaluate and discuss the definition of $2 \mathrm{G}$ bioethanol and its future.
\end{abstract}

Keywords: 2G bioethanol, Straw, Raw material volume, Question.

\section{Introduction}

The technology to produce alcohol (ethanol) from sugar and starch crops is quite mature and reliable [1].

In 2014,Inbicon Demonstration Plant(Inbicon D Plant) [2] had successfully completed the industrial scale fermentation experiment on making ethanol from straw and its C6 (from cellulose) + C5 mix sugars(from hemicellulose)[3].This kind of ethanol is called Cellulose ethanol or 2G Bioethanol.

To this date, the test data published by Inbicon D Plant are the most complete, the most reliable and the most valuable $2 \mathrm{G}$ bioethanol reference data. They are also the basis of Denmark's 2G Bioethanol Industrial Plan-Straw plan [3,4].

Test data published by Inbicon D Plant are: It is 231 kilo ethanol per. tonnes of straw (calculated as straw with $100 \%$ dry matter), 374 kilo of lignin and 80 kilo of vinasse[5].

This paper is the results of gathering data first and then comparing the data against that of sugar crops, starch crops, and Straw, analyzing and proofing the existing problems of $2 \mathrm{G}$ bioethanol.

In it, starch crops uses the data of Wheat plan that were already being denied [6], and Sugar crops use the data from the UF/ IFAS Hastings Agricultural Extension Center Sweet Sorghum (M81) or Canada's sugarcorn [7], shortened and called B-plan.

\section{Carbohydrates Calculation}

In this paper, sugar, starch and $\mathrm{C} 5+\mathrm{C} 6$ mix sugars are called Carbohydrates or fermentable sugars. In theory, 1.9553 tons of sugar can be fermented into 1 ton of ethanol. 
Table 1 shows the basic data of sugars or starch conversion into bioethanol. According to chemical reaction equations plus losses $(\approx 0.074 \%)$, approximately, 2.10 tons sugars or starch can be converted into 1.0 ton bioethanol.

Table 1: Table 1: Fermentation Processes/Chemical Reaction Equations

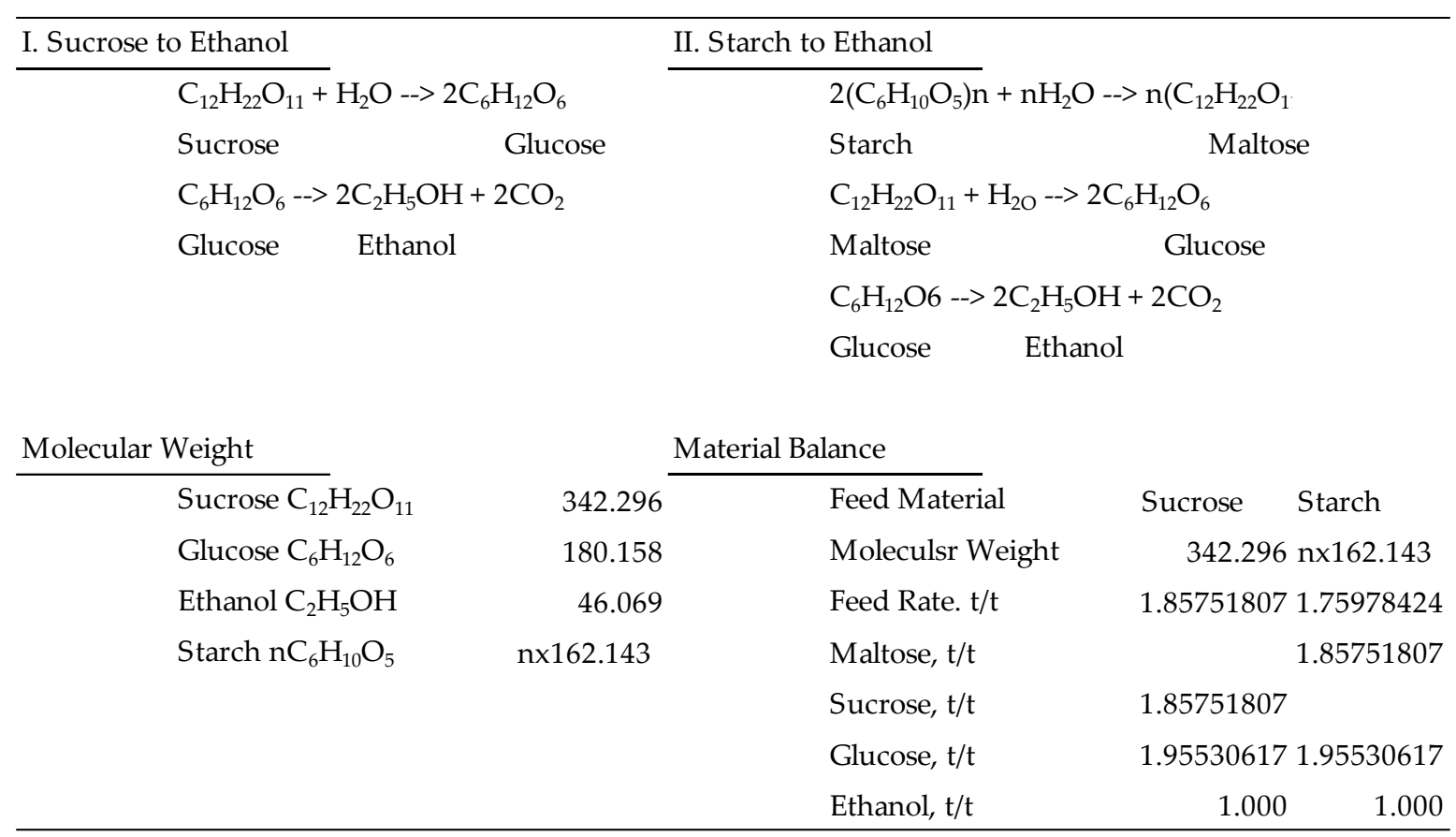

Inbicon D Plant data: 2.36 tons $\mathrm{C} 5+\mathrm{C} 6$ mixed sugar can be converted into 1.0 ton bioethanol. Inbicon data calculation process is not expressed in this table.

Figure 1: Carbohydrates required to produce 1.0 ton of bioethanol $(\mathrm{t} / \mathrm{t}$ ethanol $)$

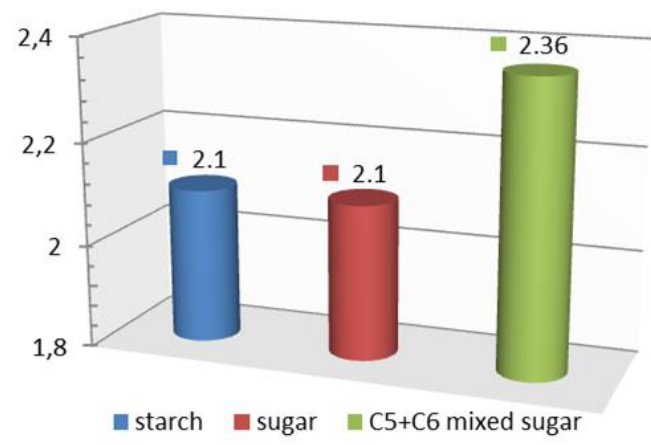

\section{Raw Material Feed Calculation}

Wheat plan and straw Plan are actual examples of industrial operation. Their raw material feed quantities can be found in the following brief description. However, the raw material feed quantity of B-plan still needs to be calculated from Table 1.

\subsection{Wheat plan(Starch crops) [8]}

W-plan was started around 2007. It uses 530000 tons of winter wheat, produces 200 million liters bioethanol and 115000 tons protein (dry basis), etc. byproducts. Proteins are valuable items in the market and there is a strong demand for these products. Because wheat is considered to be a food item, the W-Plan was forced to be shut down in 2014. 
Manufacturing process and technology for W-Plan is mature and well understood and there are examples of successful commercialization[9, 10].thus, the risk is low. Because wheat gluten and Bstarch (15 - $20 \%$ ) [11], etc., would require some special treatments, therefore, its wastewaters are difficult to treat.

In it, bioethanol calculation is based on $1000 \mathrm{~kg}=1267$ liter, and 200 million liters bioethanol $\approx$ 157853 ton bioethanol, amounted to using 3.358 tons wheat to produce1.0 ton bioethanol.

\subsection{Straw plan (Lignocellulosic) [12]}

The Danish word for "straw" is halm. S-Plan was started around 2009; it uses 300000 tons straw to produce77million liters ( $\approx 60773 \mathrm{t})$ bioethanol, 92000 tons vinasse and 92000 tons lignin, etc. byproducts. S-Plan is a typical cellulosic ethanol, and it is the important analysis point of this paper.

Presently, cellulosic ethanol is in various experimental stages of development and there is no single example of successful commercialization here in the EU region and USA [13,14]. S-Plan is rather controversial [15].

Based on calculation 300000t straw to produce 60773t bioethanol, 4.936t straw can produce 1.0 ton bioethanol. After deducting $12.3 \%$ moisture content, there is 4.33 t straw (100\% Dry Matter) remaining to produce 1.0 ton bioethanol. This is in agreement with the data of Inbicon D Plant, which is a small S-Plan demonstration plant in Denmark [2].

\subsection{B-plan (Sugar crops)}

Sugarcorn (with high stalk sugar content) [16] is a new energy crop from Canada. With the development of the agricultural technology it might replace sugarcane [17] and sweet sorghum $[18,19]$, its stalk Juice contains ample amount of carbohydrates (C6 sugar), that can be fermented into ethanol.

Carbohydrates in sweet sorghum or corn stalk juice (S-Juice) are non-crystalizabled, with odor, so it is unsuitable as a sweetener for human consumption, but, it can be a raw material for animal feeds or bioethanol. After their grains are harvested and if their stalks are not processed into other products, S-Juice shall be converted into lignocellulose within a few days.

Extraction of S-Juice and its concentration shall be accomplished by using the same processes we utilized in 2015 for sweet sorghum crop at the University of Florida's IFAS Hastings Agricultural Extension Center in USA.
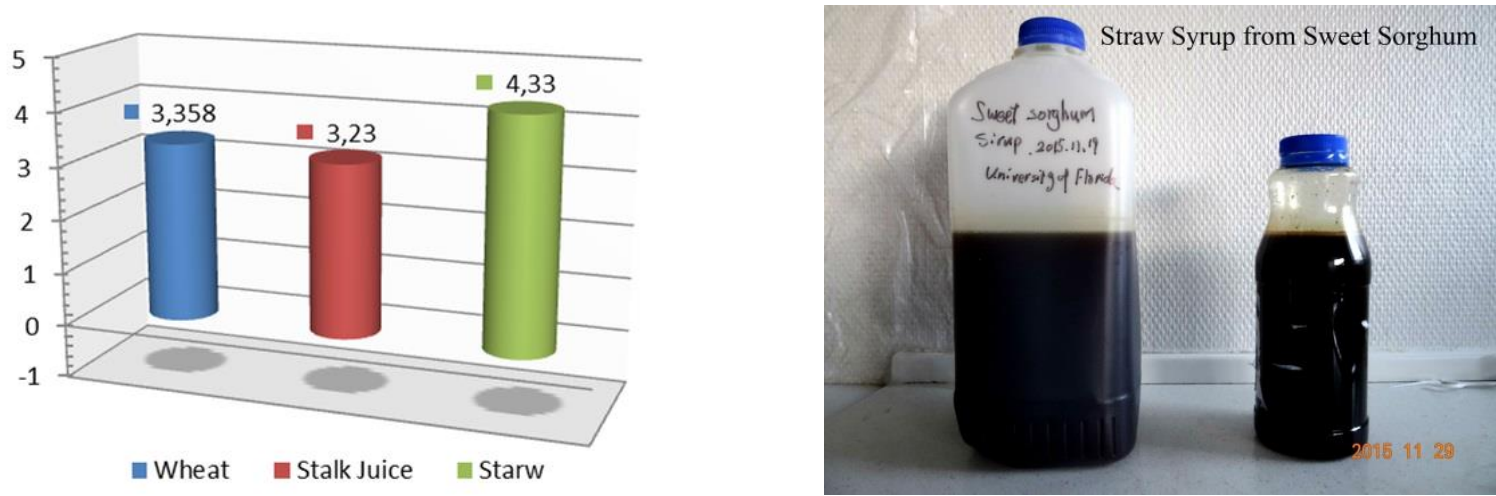

Figure 2: Raw material required for 1-ton bioethanol ( $\mathrm{t} / \mathrm{t}$ ethanol)

From Table 1 and The Sugar Engineers[20]; 3.23t S-Juice (65\%Brix, $200{ }^{\circ} \mathrm{C}$, Purity 80\%, Density $1317.6 \mathrm{~kg} / \mathrm{M}^{3}$ ) would is required to produce $1.0 \mathrm{t}$ bioethanol.

\subsection{Ethanol Conversion Rate}

Ethanol conversion rate can be obtained from carbohydrates and raw material feed quantity. Ethanol conversion rate is one of the important indicators for evaluation of $2 \mathrm{G}$ bioethanol processes. 


$$
\text { Ethanol Conversion Rate }=\frac{\text { Carbohydrates }}{\text { Rawmaterial Feed Quantity }}
$$

Table 2: Ethanol Conversion Rate Calculation (\%)

\begin{tabular}{lccc}
\hline NAME & Carbohydrate & Feed Quantity & $\begin{array}{c}\text { Ethanol } \\
\text { Conversion } \\
\text { Rate }\end{array}$ \\
\hline Wheat & 2.1 & 3.358 & $62.54 \%$ \\
Stalk Juice & 2.1 & 3.23 & $65.02 \%$ \\
Straw & 2.36 & 4.33 & $54.50 \%$ \\
\hline
\end{tabular}

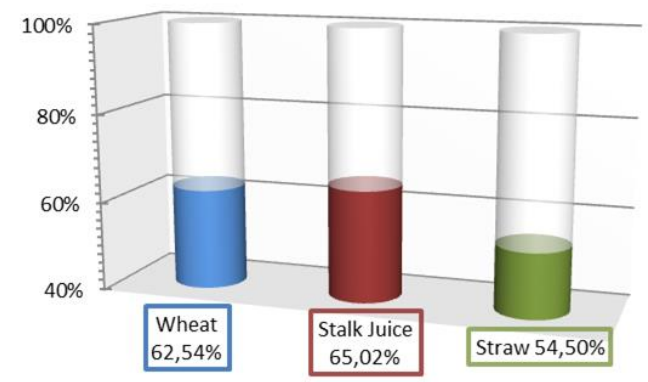

\section{Raw Material Volume Calculation}

Because raw material runs through the entire 2G bioethanol production process, its volume has direct effect on the major flow line sizes, equipment number, building, and capital expenditure of its production line. Therefore, it is necessary to calculate the volume of the raw material.

\subsection{Bulk Density of Raw Materials}

Bulk density (or density) is related to its volume. Volume data can be obtained through bulk density data.

Bulk density: Raw material weight $(\mathrm{t}) /$ Volume $\left(\mathrm{M}^{3}\right)$ usually expressed in $\mathrm{t} / \mathrm{M}^{3}$.

Bulk density data are as follows; wheat $0.77\left(\mathrm{t} / \mathrm{M}^{3}\right)$ [21,22], S-Juice 1.317(t/M3) (Temperature 200 ${ }^{0} \mathrm{C}$, Brix $65 \%$, Purity $85 \%$ ).

During transportation and in a production process, except wheat and S-Juice, there are relatively large changes in bulk density of crop stalks.

Table 3: Bulk Density of Raw Material (t/M³)

\begin{tabular}{lc}
\hline \multicolumn{1}{c}{ Raw Material } & Bulk Density \\
\hline Wheat & 0.77 \\
Stalk Juice & 1.317 \\
Straw (VO\#140) & 0.14 \\
Straw (VO\#280) & 0.28 \\
\hline
\end{tabular}

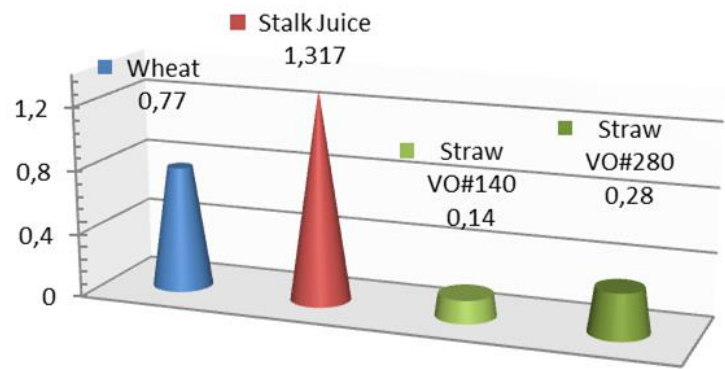

- During transportation; its stalks after being compressed, its bulk density is around $0.10\left(\mathrm{t} / \mathrm{M}^{3}\right)$ [23] $\sim 0.28\left(\mathrm{t} / \mathrm{M}^{3}\right)$ [24]. Therefore, during transportation, use $0.28 \mathrm{t} / \mathrm{M}^{3}$ for stalk calculations, marked as $\mathrm{VO} \# 280$.

- During production; straw after pulverizing, its bulk density is still going lower. Such as, lowering to $0.045 \mathrm{t} / \mathrm{M}^{3}-0.140 \mathrm{t} / \mathrm{M}^{3}$, similar to letpressede baller. As an example, in 2017 , a steam explosion test system feed density was $100 \mathrm{~kg} 125 / \mathrm{M}^{3}$ [25]. In this paper, $140 \mathrm{Kg} / \mathrm{M}^{3}$ is used for calculation, marked as VO\#140.

\subsection{Raw Material Volume Calculation}

Using bulk density the raw material volume can be obtained. It is usually expressed in $\mathrm{M}^{3}$.

To produce 1 ton of bioethanol, the formula for raw material volume is: Usually expressed as $\mathrm{M}^{3} / \mathrm{t}$ ethanol. 


$$
\text { Raw Material Volume }=\frac{\text { Mass of Raw Material }\left(\frac{\mathrm{t}}{t_{\text {ethanol }}}\right)}{\text { Raw material Material Bulk Density }\left(\frac{\mathrm{t}}{M^{3}}\right)}
$$

Table 4: Volume Calculation for Various Raw Materials ( $\mathrm{M}^{3} / \mathrm{t}$ ethanol)

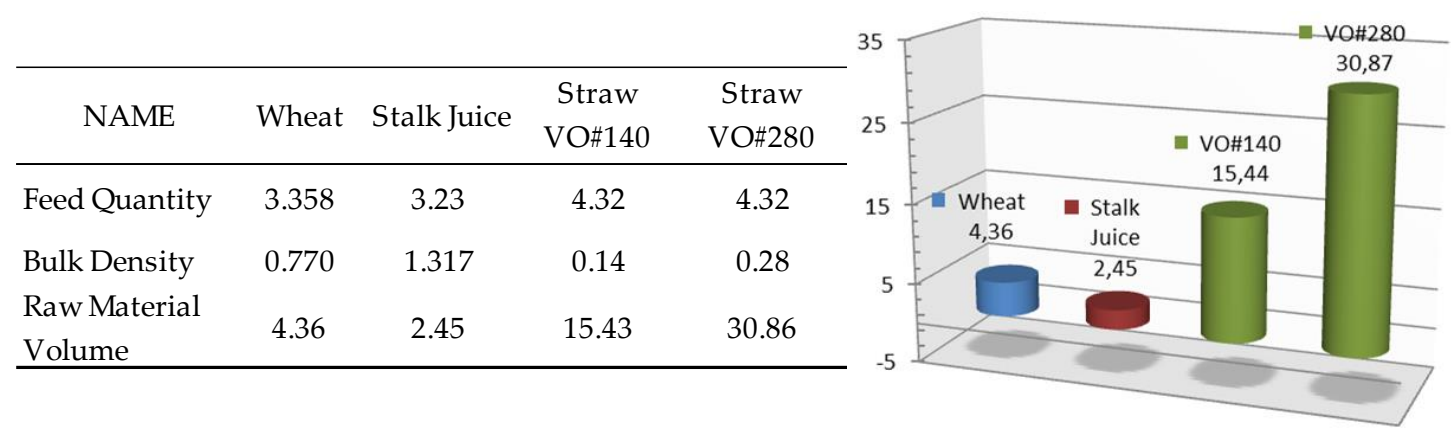

\section{Hypothesis and Calculation}

This paper utilizes the coefficient of variation (C.V.) to analyze straw data. Because $2 \mathrm{G}$ bioethanols and their production processes consisted of many different technologies, therefore, their C.V. threshold values can be hypothesized separately as follows:

1. Sample values of sugar and starch are all mature and reliable data, and they are regarded as comparative group data. Straw sample values VO\#140 and VO\#280 are also regarded as test group data. The extent of variability of C.V. values is only related to sample values.

2. C.V. threshold of fermentation technology area follows the common practice and hypothesized to be $<15 \%$ [26]. If the C.V. value is $>15 \%$, it shows the existence of risks, should reject or deny.

3. Raw material volume and equipment dimensions, quantity, and efficiency, etc., are closely related, encompassing many industrial technologies, giving a larger development space. Thus, their C.V. threshold values can be widen to $<95 \%$. If C.V. value is $>95 \%$, proportional to pipeline dimensions, equipment number, and capital expenditure, etc. Under the same production quantity conditions, pipeline dimensions, equipment number, and building and its costs - capital expenditure of $2 \mathrm{G}$ bioethanol plant shall be about 7 times (30.87/4.36) indicating it is in the outliers, with high risks, should be denied or rejected.

Table 5: Coefficient of Variation (C.V. \% ) Calculation

\begin{tabular}{lccccc}
\hline \multicolumn{1}{c}{ NAME } & Carbohydrates & $\begin{array}{c}\text { Feed } \\
\text { Quantity }\end{array}$ & $\begin{array}{c}\text { Ethanol } \\
\text { Conversion }\end{array}$ & $\begin{array}{c}\text { Volume } \\
\text { VO\#140 }\end{array}$ & $\begin{array}{c}\text { Volume } \\
\text { VO\#280 }\end{array}$ \\
\hline Starch/Wheat & 2.1 & 3.358 & $62.54 \%$ & 4.36 & 4.36 \\
Sugar/Stalk Juice & 2.1 & 3.23 & $65.02 \%$ & 2.45 & 2.45 \\
C5+C6 mix sugar/Straw & 2.36 & 4.33 & $54.50 \%$ & 15.44 & 30.87 \\
COUNT & 3 & 3 & 3 & 3 & 3 \\
Standard Deviation & 0.1501 & 0.6015 & 0.0549 & 7.0137 & 15.8856 \\
Mean & 2.1867 & 3.6393 & 0,6068 & 7.4167 & 12.56 \\
Coefficient of Variation & 0.0686 & $0.1653 *$ & 0.0905 & 0.9456 & 1.2648 ** \\
(C.V.\%) & & & & & \\
\hline
\end{tabular}

$0.1653^{*} \& 1.2648^{* *}$ are outliers.

\section{6. $\quad$ Results}

Based on the above calculation and hypothesis, the following conclusions can be reached:

1. For ethanol conversion rate C.V. values of $0.08932<0.15$, there is no risk, data are useful. Ethanol conversion rate is the overall indicator for carbohydrate (0.0686) and feed quantity (0.1639) data, representative ones. Indicating the $\mathrm{C} 5+\mathrm{C} 6 \mathrm{mix}$ sugar (2.36t/t Ethanol) 
fermentation efficiency is very close to that of sugar and starch (2.1t/t Ethanol), their fermentation technology and process are both mature and reliable, there are none technical risks.

2. Volume \#1(15.44M3/t Ethanol) C.V. value $0.9457<0.95$ indicating; when straw $\geq 0.28 t / \mathrm{M} 3$ there is a risk, but $2 \mathrm{G}$ bioethanol project is still feasible.

3. Volume $\# 2(30.87 \mathrm{M} 3 / \mathrm{t}$ Ethanol) its C.V. value $1.2648>0.95$ is within outlier value, there is high risk, should be denied. When straw $<0.28 \mathrm{t} / \mathrm{M} 3,2 \mathrm{G}$ bioethanol and its project are in a highrisk area, should be denied.

\section{Discussion}

Wheat is a food. It is already being eliminated for consideration. But its production process data are the important reference value for $2 \mathrm{G}$ bioethanol.

When C.V. value of ethanol conversion rate is 0.08932 , indicating: It only needs 4.33 tons straw or 3.358 tons wheat to produce 1 ton ethanol. In comparison, straw has a commanding raw material cost advantage over wheat.

When C.V. value is 0.9457 that is $<0.95$, the straw volume is $15.44 \mathrm{M} 3 / \mathrm{t}$ Ethanol, bulk density is $0.28 \mathrm{t} / \mathrm{M} 3$. This time, building and its cost --- capital expenditure for $2 \mathrm{G}$ bioethanol plants are approximately 3.5 times that of wheat ethanol plant (15.44/4.32). Therefore, it seems that if straw $\geq 0.28 \mathrm{t} / \mathrm{M} 3,2 \mathrm{G}$ bioethanol project has an ample development space and feasibility.

When C.V. value is $1.2648>0.95$, it needs 30.87 cubic meters (Bulk density $0.14 \mathrm{t} / \mathrm{M} 3$ ) straw to produce 1 ton bioethanol. Suppose the raw material volume is direct proportional to pipeline dimensions, equipment number, and capital expenditure, etc. Under the same production quantity conditions, pipeline dimensions, equipment number, and building and its costs - capital expenditure of $2 \mathrm{G}$ bioethanol plant shall be about 7 times (30.87/4.36) that of wheat ethanol plant. This can also be explained as: Under the same production quantity conditions, the capital expenditure of wheat ethanol plant shall probably be just one-seventh of $2 \mathrm{G}$ bioethanol plant.

This should be one of the important reasons why $2 \mathrm{G}$ bioethanol is so expensive, lack of competitiveness, and requiring long-term government subsidies. Because there are no evidence to prove that by increasing the production scale it can lower the straw volume. Thus, regardless of what production line scale is, when the bulk density of straw is $<0,28 t / M 3$, there is a huge risk for $2 G$ bioethanols, thus, it is not feasible at all.

Seven times investment amount means there shall be 7 times consumption of cement as well as steel, and 7 times $\mathrm{CO} 2$ emissions. Thus, there are ample reasons to question the $\mathrm{CO} 2$ emissions and its carbon footprint of $2 \mathrm{G}$ bioethanol plant. Important point is that volume is not the only existing problem, it is necessary to re-evaluate and discuss the definition of $2 \mathrm{G}$ bioethanol and its future.

Because the $2 \mathrm{G}$ bioethanol has the above mentioned uncertainty and risk, thus, it will possible in need of the B-plan. For example, by the way of agricultural technology and genetic engineering to bring forth new improved sugarcorn, sweet sorghum, etc., C4 crops; heighten the use of carbohydrates in their stalks, should also be some of the important directions for $2 \mathrm{G}$ bioethanol.

Author Contributions: Conceptualization, Y.L. and R.L.; writing-original draft preparation and editing, Y.L.; writing-review, R.L. and J.T.

Funding: This research received no external funding.

Acknowledgments: We would like to express our thanks to UF/IFAS Extension Johns County and UF/ IFAS Hastings Agricultural Extension Center and all those personnel who had assisted us in completing the project test and data gathering at their location, and especially to Professor Daniel J.Cantliffe, Director Scott Taylor and etc. for their efforts in promoting our test program.

1. Professor Daniel J. Cantliffe, Dr. Bonnie C. Wells, UF/IFAS Extension Johns County, St Augustine, FL 32092, USA.

2. Scott Taylor, Scott D. Chambers, Candy, Pan and etc., UF/ IFAS Hastings Agricultural Extension Center, Hastings, Florida 32145-0728, USA.

3. Tyler G. Trimmer, Bob. Johnston, Vincent Corporation, Tampa, Florida 33605, USA.

4. Lilian P. Kloster and colleagues, Boeslum Renseanlaeg, 8400 Ebeltoft, Denmark. 
5. Jan Larsen, Niels Henriksen; DONG Energy, 7000 Fredericia, Denmark.

Conflicts of Interest: The authors declare no conflict of interest.

\section{References}

1. Stewart, G. G., et al. "Biology of ethanol-producing microorganisms." Critical Reviews in Biotechnology 1.3 (1983): 161-188.

2. Michael Persson, et al."Inbicon demonstration plant", European Biofuels Technology Platform 3rd Stakeholder Plenary Meeting Brussels, April 14, 2010

3. Jan Larsen \& Niels Henriksen (2015).Status for the Inbicon technology by end of 2014.DONG Energy, Denmark. http://docplayer.net/33966324-Status-for-the-inbicon-technology-by-end-of-2014.html

4. Jim Lane, Inbicon: Biofuels Digest's 2015 5-Minute Guide.BiofuelsDigest, April,2015. http://www.biofuelsdigest.com/bdigest/2015/04/01/inbicon-biofuels-digests-2015-5-minute-guide/

5. Sanne Wittrup"Inbicon lægger data frem: Så effektiv er vores bioethanol-proces",Ingeniøren,marts, 2015, https://ing.dk/artikel/inbicon-laegger-data-frem-saa-effektiv-er-vores-bioethanol-proces-175036

6. TOMMY LOBERG JØNS,"Bioraffinaderi på Grenaa Havn sat på standby", Randers Amtsavis,februar 2015 https://amtsavisen.dk/norddjurs/Bioraffinaderi-paa-Grenaa-Havn-sat-paa-standby/artikel/186708

7. L.M. Reid, M.J. Morrison, X. Zhu, K.K. Jindal, B.L. Ma, High stalk sugar corn: a potential biofuel crop for Canada, Agron. J. 107 (2) (2015).

8. BIORAFFINADERI TIL PRODUKTION AF BIOENERGI I REGION MIDTJYLLAND,Marts 2012,Af Eva Søndergaard,Niels Ove Nielsen,Nicolaj Ingemann Nielsen, Kasper Stefanek,AgroTech og Nuria Canibe,Aarhus University,Marts 2012

9. Li sheng, , et al. Energy gain of wheat ethanol in China, Acta Ecologica Sinica 2007,27(9):3794 3800 李胜, 路明,杜凤光.中国小麦燃料乙醇的能量收益. 生态学报,2007,27(9):3794 3800.

10. Yan, Xiaoyu, and Adam M. Boies. "Quantifying the uncertainties in life cycle greenhouse gas emissions for UK wheat ethanol." Environmental Research Letters 8.1 (2013): 015024.

11. Lars Olav Thomsen, "OCCURRENCE OF STARCH", International Starch Institute, Denmark, http://www.starch.dk/isi/starch/tm33wheat.asp

12. STATUSES REPORT THE DAWNING OF DANISH BIO-ECONOMY, Summary of the Business Plan, MEC I/S, Denmark.https://www.maabjergenergycenter.dk/media/1433/statusrapport2015 uk web.pdf

13. Gregg, Jay Sterling, et al. "Value Chain Structures that Define European Cellulosic Ethanol Production" Sustainability 9.1 (2017): 118.

14. Dale, B. (2018). “Time to Rethink Cellulosic Biofuels?.” Biofuels, Bioproducts and Biorefining, 12(1), 5-7. DOI: 10.1002/bbb.1856

15. Sanne Wittrup,Omstridt bioethanolfabrik udskydes tre år, Ingeniøen,aug 2016, https://ing.dk/artikel/omstridt-bioethanolfabrik-udskydes-tre-aar-186248

16. L.M. Reid, X. Zhu, K.K. Jindal, A.Z. Kebede, J. Wu, M.J. Morrison, Increasing stalk sucrose in sugarcorn (Zea mays L.): genetic analysis and preliminary breeding, Euphytica 209 (2) (2016) 449-460.

17. Gomez-Flores R, Thiruvengadathan $\mathrm{T}$ N, Nicol R, et al. Bioethanol and biobutanol production from sugarcorn juice [J]. Biomass and Bioenergy, 2018, 108: 455-463.

18. Barcelos, C. A., et al. "Ethanol production from sorghum grains [Sorghum bicolor (L.) Moench]: evaluation of the enzymatic hydrolysis and the hydrolysate fermentability." Brazilian Journal of Chemical Engineering 28.4 (2011): 597-604.

19. Kim, Misook, and Donal F. Day. "Composition of sugar cane, energy cane, and sweet sorghum suitable for ethanol production at Louisiana sugar mills" Journal of industrial microbiology \& biotechnology 38.7 (2011): 803-807.

20. Wayne Jayes, Density of Sugar Factory Products, The Sugar Engineers, Tongaat 4399 KZN South Africa. http://www.sugartech.co.za/density/index.php

21. Food Products - Bulk Densities, Bulk densities of some common food products, Engineering ToolBox. http://www.engineeringtoolbox.com/foods-materials-bulk-density-d 1819.html

22. FAO/INFOODS) Density) Database) Version) 2.0) (2012),FAO/INFOODS Food Composition Databases. http://www.fao.org/docrep/017/ap815e/ap815e.pdf 
23. Villy Nielsen,"Teknik til halmbjærgning siden midten af det forrige århundrede",Danmarks JordbrugsForskning,Januar,2003, http://www.videncenter.dk/halmbjergning 1950 2000.pdf

24. Densitet (volymvikt) för vissa jordbruks- och fabriksprodukter, http://www.agriwise.org/demo/databok2010htm/kap27b/01 Densitet.htm

25. Yangsheng Lu \& Jens Kirk Thomsen, "Unpublished Steam explosion test data", International Starch Institute, Denmark, 2017

26. "Calculating Inter- and Intra-Assay Coefficients of Variability", Salmetrics LLC, 5962 La Place Court, Suite 275, Carlsbad, CA 92008, $\quad$ https://www.salimetrics.com/calculating-inter-and-intra-assaycoefficients-of-variability/ 